\title{
PENGARUH MODAL KERJA TERHADAP PROFITABILITAS \\ STUDI PADA PERUSAHAAN MANUFAKTUR YANG TERDAFTAR DI BURSA EFEK INDONESIA
}

\author{
Eva Larasati \\ Selmita Paranoan \\ Jurusan Akuntasi Fakultas Ekonomi Universitas Tadulako \\ No Telp: 081843844734; e-mail: Shelo0709@yahoo.co.id dan evalarasry@gmail.com
}

\begin{abstract}
Indonesia had instability economics situation which can affect to how manage an efficient working capital then capable to increase a profitability. This research is aimed to test how a working capital (which is sales growth ratio, financial debt ratio, fixed financial assets ratio, number of days accounts receivable, number of days inventories, number of days accounts payable, cash conversion cycle) can influenced a profitability of food and beverages companies. This Research is implemented to 12 Foods and Beverages company which is listed in The INDONESIA Stock Exchange from 2006-2011. Meanwhile, the evaluation of annual performance of this companies had audited from chosen public accountant. Data of financial statement as the object for this research was 5 years financial statement, from 2006 until 2011. Data of this research which has been used is secondary data with purposive sampling method. Analysis method used for this research is multi regression analysis.There was one of variable, a number of days account payable, must removed from a model based on enter removed test. The results is all independed variables can influenced to profitability simultanoues. But the only one of independend variable, number of days inventories can affect to profitability, when it tested partially.
\end{abstract}

Keyword : working capital, profitability

\begin{abstract}
ABSTRAK
Indonesia memiliki ketidakstabilan situasi ekonomi yang dapat mempengaruhi cara mengelola efisiensi modal kerja yang mampu meningkatkan profitabilitas. Penelitian ini bertujuan untuk menguji bagaimana modal kerja (yang merupakan sales growth ratio, financial debt ratio, fixed financial assets ratio, number of days accounts receivable, number of days inventories, number of days accounts payable, cash conversion cycle) dapat dipengaruhi profitabilitaspada perusahaan makanan dan minuman.Penelitian ini dilaksanakan untuk 12 Perusahaan Makanan dan Minuman yang terdaftar di Bursa Efek Indonesia tahun 2006-2011. Evaluasi kinerja tahunan perusahaan telah diaudit dari akuntan publik yang dipilih. Obyek penelitian ini adalah Data laporan keuangan selama 5 tahun, dari 2006 sampai 2011. Data dari penelitian ini yang telah digunakan adalah data sekunder dengan metode purposive sampling. Metode
\end{abstract}


analisis yang digunakan dalam penelitian ini adalah analisis regresi berganda.Salah satu variabel, number of days account payable (jumlah hari akun hutang), harus dihapus dari model yang didasarkan pada Analisis Entered/Removed. Hasil penelitian menunjukkan semua variabel Independen dapat berpengaruh terhadap profitabilitas secara simultan. Namunhanya satu variabel independen yaitunumber of days inventories(jumlah hari persediaan) dapat mempengaruhi profitabilitas, ketika diuji secara parsial.

Kata kunci: Modal kerja, Profitabilitas

\section{PENDAHULUAN}

Setiap perusahaan selalu membutuhkan modal kerja untuk membiayai operasinya sehari-hari, misalkan untuk memberikan persekot pembelian bahan mentah, membayar upah buruh, gaji pegawai, dan lain sebagainya, dimana dana yang telah dikeluarkan itu diharapkan dapat kembali lagi masuk dalam perusahaan dalam waktu yang pendek melalui hasil penjualan produksinya. Uang yang masuk berasal dari penjualan produk tersebut akan dikeluarkan lagi untuk membiayai operasi selanjutnya (Handoyo, 1997:81).

Pengelolaan modal kerja sangat penting karena menyangkut penetapan kebijakan modal kerja maupun pelaksanaan kebijakan modal kerja tersebut dalam operasi seharihari. Manajemen modal kerja berkepentingan terhadap keputusan investasi pada aktiva lancar dan hutang lancar. Terutama mengenai bagaimana menggunakan dan komposisi keduanya akan mempengaruhi resiko. Modal kerja terdiri dari empat komponen utama yaitu kas, surat berharga, persediaan dan piutang usaha, dimana komponenkomponen tersebut akan menjamin kontinuitas dan likuiditas perusahaan. Dengan modal kerja tersebut operasi perusahaan akan berjalan dengan ekonomis dan efisien (Van Horne, 1995:218).

Deloof (2003) meneliti hubungan antara modal kerja dengan profitabilitas terhadap 1009 perusahaan non financial Belgia dari tahun 1992 sampai dengan tahun 1996. Hasilnya menemukan adanya hubungan financial debt ratio, number of days 
accounts receivable, number of days inventories, number of days accounts payable terhadap gross operating income adalah negative dan pengaruhnya sangat signifikan. Artinya apabila financial debt ratio, number of days accounts receivable, number of inventories, number of days accounts payable, mengalami penurunan, maka akan ada kenaikan gross operating income.

Yunus (2005) meneliti pengaruh modal kerja terhadap profitabilitas pada perusahaan makanan dan minuman yang terdaftar di Bursa Efek Indonesia. Hasilnya menunjukkan bahwa financial debt ratio, fixed financial assets ratio and number of days accounts receivableberpengaruh secara simultan terhadap gross operating income ratio.Financial debt ratio, fixed financial assets ratio, number of days accounts receivable berpengaruh secara parsial terhadap gross operating income ratio. Namun, sales growth ratio, number of days inventories and cash conversion cycle tidak berpengaruh terhadap gross operating income ratio.

Dengan mengacu pada penelitian Deloof (2003) dan Yunus (2005), penelitian ini ingin meneliti kembali tentang pengaruh perubahan modal kerja terhadap perubahan profitabilitas pada perusahaan manufaktur go publik di BEI. Perbedaan penelitian ini dengan penelitian sebelumnya, adalah penelitian Deloof(2002) hanya melihat hubungan antara modal kerja dengan profitabilitas dan Yunus (2005) telah menguji pengaruh modal kerja terhadap profitabilitas pada perusahaan industri makanan dan minuman, sedangkan pada penelitian ini merupakan uji pengaruh atas modal kerja terhadap profitabilitas pada perusahaan manufaktur yang terdaftar di BEI dari tahun 2006 sampai 2011. Dalam kurun waktu tersebut, kondisi ekonomi Indonesia mulai bergejolak karena adanya isu krisis keuangan pada tahun 2008 yang menyebabkan saham-saham perusahaan besar terkoreksi secara signifikan, bahkan 
tersingkir dari lantai bursa.

\section{TINJAUAN PUSTAKA DAN PENGEMBANGAN HIPOTESIS}

Menurut Weston and Brigham (1993 : 353), modal kerja adalah investasi perusahaan pada aktiva jangka pendek seperti kas, surat berharga, persediaan dan piutang dagang. Salah satu factor yang mempengaruhi jumlah modal kerja adalah cash conversion cycle, yaitu jangka waktu rata-rata sejak dilakukannya pengeluaran tunai untuk sumber dana produksi (bahan baku dan tenaga kerja) hingga diterimanya uang hasil penjualan produksi. Didalamnya terdiri dari number of days inventories ditambah number of days accounts receivable dikurang dengan number of days accounts payable. Disini dapat dikatakan bahwa semakin besar jumlah cash conversion cycle, maka semakin besar kebutuhan perusahaan akan pendanaan eksternal atau dari luar. Hal ini berarti bahwa pengurangan modal kerja berarti peningkatan perputaran modal kerja. Kenaikan persediaan dapat dikaitkan dengan peningkatan hutang dagang, dimana dapat menganggu kemampuan perusahaan dalam memperoleh laba (profitabilitas perusahaan) sehingga dibutuhkan pengelolaan modal kerja yang efektif yang dapat meningktkan laba operasi perusahan. Investasi pada modal kerja memerlukan biaya, dengan demikian penurunan modal kerja akan menurunkan biaya modal dan berarti ada penghematan sehingga dapat meningkatkan profitabilitas perusahaan.

Profitabilitas adalah kemampuan perusahaan memperoleh laba dalam hubungannya dengan penjualan, total aktiva, maupun modal sendiri (Sartono, 1998:130). Jumlah laba bersih kerap dibandingkan dengan ukuran kegiatan atau kondisi keuangan lainnya seperti penjualan, aktiva, ekuitas pemegang saham untuk menilai kinerja sebagai suatu persentase dari beberapa tingkat aktivitas atau investasi. Profitabilitas merupakan salah satu jenis rasio dalam analisis laporan keuangan yang 
mengukur tingkat keuntungan suatu perusahaan. Rasio profitabilitas juga dikatakan sebagai rasio untuk mengukur kemampuan perusahaan dalam memperoleh keuntungan dari penggunaan modalnya karena menggambarkan kemampuan perusahaan mendapatkan laba melalui kemampuan dan sumber yang ada seperti kegiatan penjualan, kas, modal, jumlah karyawan, jumlah cabang dan sebagainya (Harahap, 2001;304).. Rasio ini juga disebut operatingratio. Rasio profitabilitas tergantung pada informasi akuntansi yang diambil dari laporan keuangan. Profitabilitas dalam konteks analisis rasio, mengukur pendapatan menurut laporan laba rugi dengan nilai buku investasi. Perbandingan ini disebut rasio profitabilitas (profitability ratio).

Deloof (2003) meneliti hubungan antara modal kerja dengan profitabilitas terhadap 1009 perusahaan non financial Belgia dari tahun 1992 sampai dengan tahun 1996. Penelitian tersebut membahas apakah manajemen modal kerja berpengaruh terhadap profitabilitas perusahaan-perusahaan non financial di Belgia. Adapun variable-variable yang dipakai meliputi variabel dependen yaitugross operating incomedan variabel independent yaitusales growth ratio, financial debt ratio, fixed financial assets ratio, number of days accounts receivable, number of days inventories, number of days accounts payable, cash conversion cycle. Hubungan sales growth ratio, fixed financial assets ratio terhadap gross operating income adalah positif dan pengaruhnya sangat signifikan. Artinya apabila sales growth ratio, fixed financial assets ratio mengalami kenaikan, maka gross operating income juga akan meningkat. Hasilnya menemukan adanya hubungan financial debt ratio, number of days accounts receivable, number of days inventories, number of days accounts payable terhadap gross operating income adalah negative dan pengaruhnya sangat signifikan. Artinya apabila financial debt ratio, number of days accounts receivable, number of inventories, number of days accounts 
payable, mengalami penurunan, maka akan ada kenaikan gross operating income. Hal ini sesuai dengan teori Emery (1984), piutang usaha merupakan investasi jangka pendek yang lebih menguntungkan daripada surat-surat berharga.

Yunus (2005) meneliti pengaruh modal kerja terhadap profitabilitas pada perusahaan makanan dan minuman yang terdaftar di Bursa Efek Indonesia. Hasilnya menunjukkan bahwa financial debt ratio, fixed financial assets ratio and number of days accounts receivableberpengaruh secara simultan terhadap gross operating income ratio.Financial debt ratio, fixed financial assets ratio, number of days accounts receivable berpengaruh secara parsial terhadap gross operating income ratio. Namun, sales growth ratio, number of days inventories and cash conversion cycle tidak berpengaruh terhadap gross operating income ratio.

Berdasarkan uraian tersebut, dapat digambarkan skema kerangka pemikirannya adalah sebagai berikut :

\section{Gambar 1: Skema Kerangka Pemikiran}

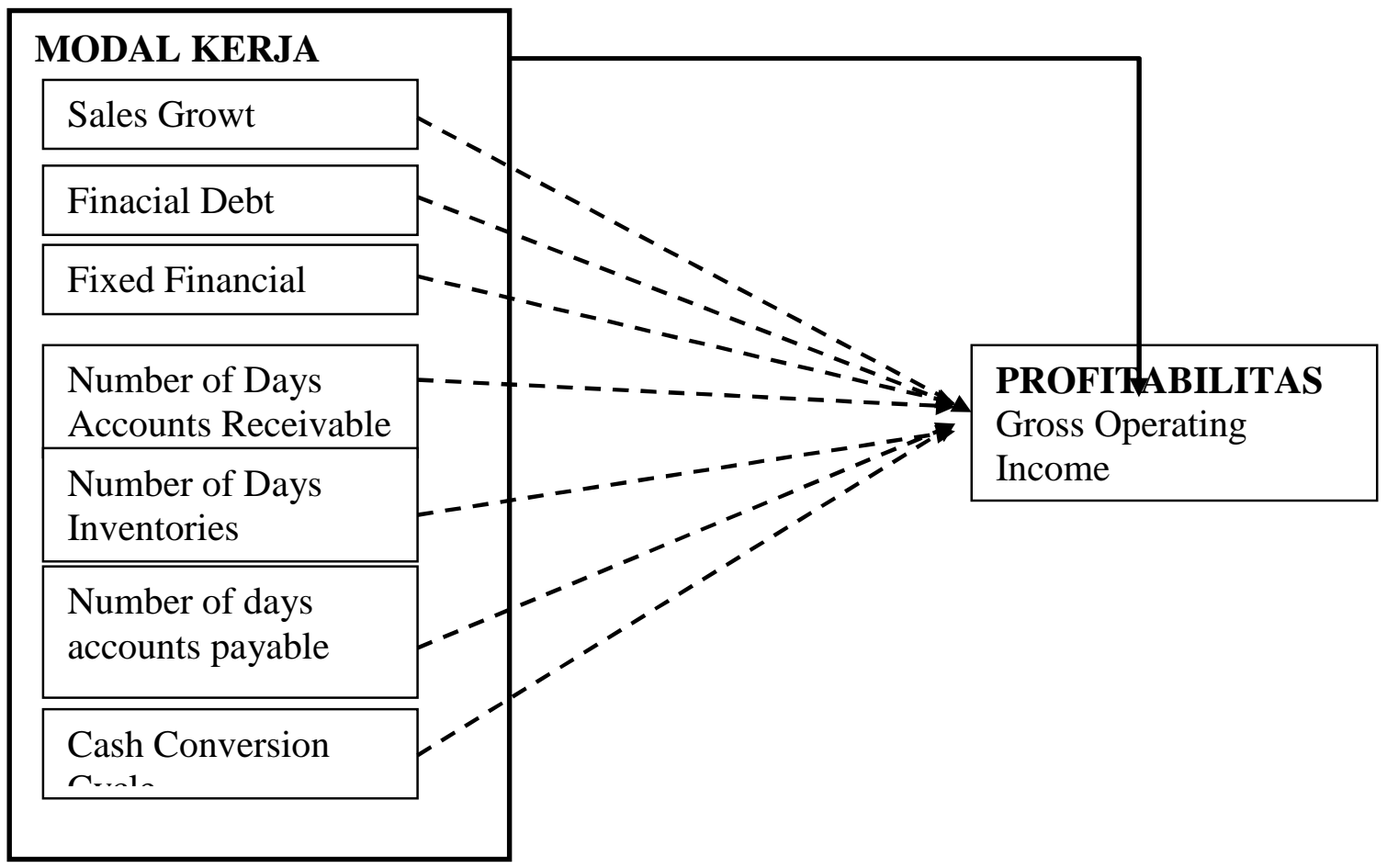


Berdasarkan tinjauan pustaka di atas, maka hipotesisnya adalah :

$\mathrm{H} 1=$ Sales growth ratio, Financial debt ratio, Fixed financial assets ratio, Number of days accounts receivable, Number of days inventories, Number of days accounts payable, Cash Conversion Cycle secara simultan tidak mempunyai hubungan linear yang signifikan terhadap profitabilitas perusahaan (gross operating income ratio).

$\mathrm{H} 2=$ Sales growth ratio, Financial debt ratio, Fixed financial assets ratio, Number of days accounts receivable, Number of days inventories, Number of days accounts payable, Cash Conversion Cycle secara simultan mempunyai hubungan linear yang signifikan terhadap profitabilitas perusahaan (gross operating income ratio).

\section{METODE PENELITIAN}

Populasi dalam penelitian ini adalah perusahaan sektor makanan dan minuman yang terdaftar di Bursa Efek Indonesia (BEI). Metode proses pengambilan sampel menggunakan metode pengambilan sampel non random dengan teknik purposive sampling. Adapun kriteria yang digunakan berdasarkan judgement atau pertimbangan tertentu. Dalam penelitian ini, sampel telah ditentukan berdasarkannkriteria sebagai berikut : (a) perusahaan yang mempublikasikan laporan keuangan sejak tahun 20062011, (b) Perusahaan menerbitkan laporan keuangannya setiap tanggal 31 Desember, (c) Perusahaan yang mencatatkan laba perusahaan selama tahun 2006-2011.

Jenisdata yang digunakan adalah data sekunder meliputi laporan keuangan perusahaan sektor makanan dan minuman.Metode pengumpulan data yang digunakan adalah metode tidak langsung. Strategi pengumpulan data menggunakan strategi arsip yaitu data dikumpulkan dari catatan atau basis data yang sudah ada.

Dalam penelitian ini, variable-variabel yang dipakai terdiri dari dua variable, yaitu variable independen $(\mathrm{X})$ dan variable dependen $(\mathrm{Y})$. Variable yang akan dianalisis dikelompokkan menjadi :

\section{Variabel Dependen}


Profitabilitas merupakan variable dependen, dan diwakili dengan Gross Operating Income ratio (GOI) adalah ratio beda antara penjualan bersih dengan harga pokok penjualan (Fraser, $2001: 284)$.

$$
G O I=\frac{\text { sales }-\cos \text { tof sales }+ \text { depreciation \& amortization }}{\text { total assets }- \text { financial assets }}
$$

\section{Variabel Independen}

Dalam penelitian ini, variabel independennya adalah Modal kerja, dengan sub variable :

1. Sales growth ratio

Sales Growth Ratio $=\frac{\text { this year's sales }- \text { previous year's sales }}{\text { previous year's sales }}$

\section{Financial debt ratio}

Financial debt ratio $=\frac{\text { Financial debt }}{\text { Total assets }}$

\section{Fixed financial assets ratio}

Fixed financial assets $=\frac{\text { Fixed financial assets }}{\text { Total assets }}$

\section{Number of days accounts receivable}

Number of days accounts receivable $=\frac{\text { Accounts } \text { Re ceivable } \times 365}{\text { Sales }}$

5. Number of days inventories

Number of days inventories $=\frac{\text { Inventories } \times 365}{\text { Cost of Sales }}$

6. Number of days accounts payable

Number of days accounts payable $=\frac{\text { Accounts Payable } \times 365}{\text { Purchase }}$

\section{Cash Conversion Cycle}

$\mathrm{CCC}=$ (Number of days accounts receivable + Number of days inventories) - Number of days payable

\section{PEMABAHASAN HASIL PENELITIAN}

\section{Uji Asumsi Klasik}

\section{Uji Normalitas}

Uji normalitas bertujuan untuk menguji apakah dalam sebuah model regresi variabel independen, variabel dependen, atau keduanya mempunyai distribusi normal atau tidak. 


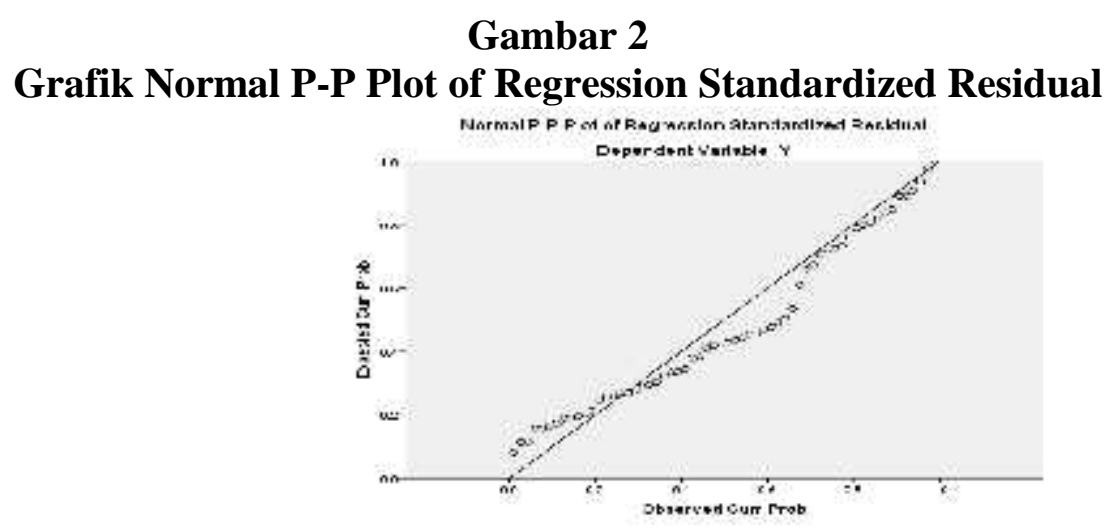

Dengan melihat tampilan grafik normal plot pada gambar di atas bahwa data menyebar disekitar garis diagonal dan mengikuti arah garis diagonal. Dengan demikian makadapat disimpulkan bahwa model regresi yang digunakan memenuhi asumsi normalitas.

\section{Uji Multikolinearitas}

Multikolinieritas terjadi apabila di antara variabel bebas memiliki hubungan yang sangat kuat atau di antara variabel bebas berkorelasi mendekati sempurna. Pengujian gejala multikolinieritas dilakukan dengan mengamati VIF (Varian Inflating Factor) yang terdapat pada kolom Collinearity Statistics pada Analisis Regresi Linier Berganda.

Tabel 1

ValueInflationFactor (VIF)

\begin{tabular}{|c|l|c|c|}
\hline & \multicolumn{1}{|c|}{ VARIABEL } & VIF & KETERANGAN \\
\hline $\mathrm{X} 1$ & Sales Growth Ratio & 1.032 & bebas multikolinearitas \\
\hline $\mathrm{X} 2$ & Financial Debt Ratio & 1.057 & bebas multikolinearitas \\
\hline $\mathrm{X} 3$ & Fixed Financial Ratio & 1.019 & bebas multikolinearitas \\
\hline $\mathrm{X} 4$ & Number of Day Acc Receivable & 1.028 & bebas multikolinearitas \\
\hline $\mathrm{X} 5$ & Number of Day Inventories & 1.27 & bebas multikolinearitas \\
\hline $\mathrm{X} 7$ & CCC & 1.299 & bebas multikolinearitas \\
\hline
\end{tabular}

Dari Tabel di atas, ditunjukkan bahwa nilai VIF untuk semua variabel bebas lebih kecil dari 10, hal ini menunjukkan tidak terdapatnya multikolinieritas.

\section{Uji Heteroskedasitas}


Uji heterokedastis dilakukan untuk menguji apakah dalam suatu model regresi terdapat ketidaksamaan varians dari residual antara satu pengamatan dengan pengamatan yang lain. Pengujian heterokedastis menggunakan grafik scatterplot untuk mendeteksi adanya heterokedastis (Ghozali, 2007). Heterokedasitas tidak terjadi jika data terpencar di sekitar angka nol (0 pada sumbu Y) dan tidak membentuk suatu pola atau tren garis tertentu.

\section{Gambar 4.1. Scatterplot}

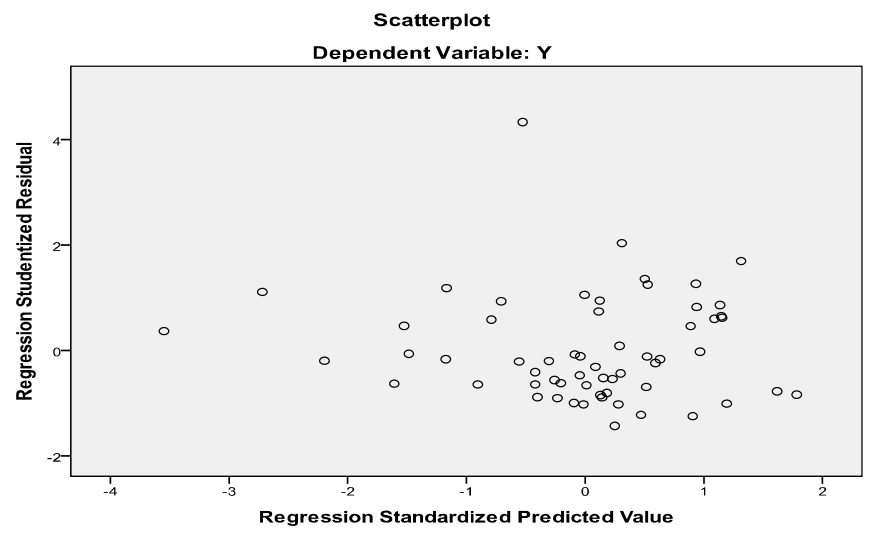

Berdasarkan hasil pengujian di atas terlihat bahwa sebaran data pada titik nol dan tidak tampak adanya suatu pola pada sebaran data tersebut. Jadi dapat ditarik kesimpulan bahwa tidak terjadi heterokedastisitas pada model regresi..

\section{UjiAutokorelasi}

Autokorelasi pada model regresi adalah adanya korelasi antar anggota sampel yang diurutkan berdasarkan waktu saling berkorelasi. Untuk mengetahui adanya autokorelasi dalam suatu model regresi dilakukan pengujian terhadap nilai Durbin Watson (DW).Dalam penelitian ini, nilai Durbin-Watson sebesar 1,649sehingga dapat ditarik kesimpulan bahwa pada model regresi tidak terdapat autokorelasi.

\section{Uji Regresi Berganda}




\section{Analisis Entered/Removed}

Sebelum membahas hasil estimasi regresi berganda, model regresi akan menentukan variabel independen yang dapat dimasukkan dalam persamaan berdasarkan tabel berikut :

Tabel 2

Variables Entered/Removed

\begin{tabular}{|l|l|l|}
\hline \multicolumn{1}{|c|}{ Variables Entered } & \multicolumn{1}{|c|}{ Variables Removed } & Method \\
\hline Sales Growth Ratio (X1) & $\begin{array}{l}\text { Number of Days Account } \\
\text { Payable (X6) }\end{array}$ & Entered \\
\hline Financial Debt Ratio (X2) & & \\
\hline Fixed Financial Ratio (X3) & & \\
\hline Number of Days Acc Receivables (X4) & & \\
\hline Number of Days Inventories (X5) & & \\
\hline Cash Conversion Cycle (X7) & & \\
\hline
\end{tabular}

Dari tabel di atas menunjukkan bahwa tidak semua variabel independen dapat dimasukkan pada persamaan tersebut. Dari ketujuh variabel independen, number of days account payable merupakan satu-satunya variabel yang dikeluarkan oleh model regresi berganda.

\section{Analisis Hasil Pengujian Regresi}

Tahap berkutnya dalam hasil estimasi regresi berganda pada penelitian ini dapat dilihat pada tabel berikut : 
Tabel 3.

Hasil Estimasi Regresi Berganda

\begin{tabular}{|c|c|c|c|c|}
\hline VARIABEL & $\begin{array}{l}\text { Unstandardized } \\
\text { Koefisien Regresi }\end{array}$ & $\begin{array}{c}\text { Standardized } \\
\text { Koefisien } \\
\text { Regresi } \\
\end{array}$ & $\mathbf{t}$ & Sig \\
\hline Sales Growth Ratio & 0.197 & 0.5 & 0.382 & 0.704 \\
\hline Financial Debt Ratio & 0.378 & 0.77 & 0.579 & 0.565 \\
\hline Fixed Financial Ratio & -0.003 & -0.137 & 1.407 & 0.300 \\
\hline Number of Day Acc Receivable & -0.002 & -0.047 & 0.359 & 0.721 \\
\hline Number of Day Inventories & -0.011 & -0.321 & -2.206 & 0.032 \\
\hline $\mathrm{CCC}$ & -0.00085 & 0.049 & -0.331 & 0.742 \\
\hline $\mathrm{R}^{2}$ (R Square) & $=0.116$ & & & \\
\hline $\mathrm{R}$ & $=0.34$ & & & \\
\hline Uji F & $=1.154$ & & & \\
\hline Sig & $=0.345$ & & & \\
\hline Konstanta & $=2.271$ & & & \\
\hline
\end{tabular}

Berdasarkan output dari hasil regresi berganda di atas, maka model regresi berganda dalam penelitian ini dapat dirumuskan sebagai berikut :

\section{Profitabilitas $=2,271+$ 0,197 Sales Growth Ratio + 0,378 Financial Debt Ratio - 0,003 Fixed Financial Ratio - 0,002 Number of Days Account Receivable - 0,011 Number of Days Inventories - 0,00085 Cash Convertion Cycle.}

Kekuatan pengaruh variabel independen terhadap varaiabel dependen dapat diketahui dari besarnya nilai koefisien determinan $\left(\mathrm{R}^{2}\right)$ yang berada diantara nol dengan satu. Nilai $\mathrm{R}^{2}$ sebesar 0,116 . Hal ini berarti 11,6 persen variabel profitabilitas dapat dijelaskan oleh variabel Sales Growth Ratio, Financial Debt Ratio, Fixed Financial Ratio, Number of Days Account Receivable, Number of Days Inventories, dan Cash Convertion Cycle. Sedangkan sisanya sebesar 88,4 persen dijelaskan oleh factor lain di luar model.

Nilai $\mathrm{R}$ sebesar 0,34 menunjukkan kekuatan hubungan antara variabel Sales Growth Ratio, Financial Debt Ratio, Fixed Financial Ratio, Number of Days Account 
Receivable, Number of Days Inventories, dan Cash Convertion Cycle terhadap profitabilitas perusahaan (Gross Operating Income) cukup lemah.

\section{Pengujian Hipotesis}

\section{Hasil Uji F (F Test)}

Pada table 3, dapat dilihat $\mathrm{F}$ hitung sebesar 1,154 dan nilai signifikansi 0,345. Dengan menggunakan tingkat $\alpha$ (alpha) 0,05 atau 5\%, disimpulkan bahwa nilai signifikansi lebih besar daripada tingkat $\alpha$. Artinya variabel Sales Growth Ratio, Financial Debt Ratio, Fixed Financial Ratio, Number of Days Account Receivable, Number of Days Inventories, dan Cash Convertion Cycle tidak berpengaruh secara simultan terhadap Profitabilitas Perusahaan (Gross Operating Income).

\section{Hasil Uji t (t Test)}

\section{Number of Days Inventories}

Number of days inventories berpengaruh secara signifikan terhadap profitabilitas perusahaan (gross operating income).Hal ini dapat dilihat dari nilai sig $=0,032$ (tabel 3.) yang lebih kecil dari taraf signifikansi 5\%. Hasil penelitian ini tidak sama dengan penelitian Yunus (2005) tetapi sama dengan penelitian yang dilakukan oleh Deloof (2003). Populasi perusahaan dalam penelitian ini adalah perusahaan di sector makanan dan minuman dengan jenis produksinya tidak tergantung pada sifat musiman atau pesanan sehingga persediaan produk diasumsikan mampu memenuhi permintaan konsumen.

\section{Sales Growth Ratio}

Sales growth ratio tidak mempunyai pengaruh terhadap gross operating income.Nilai Sig = 0,704 (tabel 3) yang lebih besar daripada taraf signifikansi 5\%. Hasil 
penelitian ini sesuai dengan penelitian Yunus (2005) tetapi tidak sesuai dengan penelitian Deloof (2003). Pada penelitian ini diasumsikan pertumbuhan penjualan dalam keadaan pasti, semua perusahaan akan memiliki jumlah aktiva lancar yang sama. Apabila ada peningkatan jumlah aktiva lancar maka akan menyebabkan makin perlunya pendanaan eksternal tanpa peningkatan laba. Dari sini dapat dikatakan bahwa sales growth ratio tidak mempunyai pengaruh yang signifikan terhadap gross operating income ratio.

\section{Financial Debt Ratio}

Financial debt ratio secara tidak mempunyai pengaruh terhadap gross operating income.Hal ini dibuktikan dari nilai Sig $=0,565$ yang lebih besar dari taraf signifikasi 5\%.(table 3)Hasil tersebut tidak sesuai dengan penelitian Yunus (2005) dan DeLoof (2003). Seharusnya, financial debt ratio akan mempengaruhi gross operating income karena hutang yang meningkat akan menyebabkan penurunan tingkat profitabilitas perusahaan.

\section{Fixed Financial Ratio}

Fixed financial assets tidak berpengaruh terhadap gross operating income. Hal ini tidak sesuai dengan penelitian Yunus (2005) dan Deloof (2003). Ini dibuktikan dari nilai $\operatorname{Sig}=0,300$ yang lebih besar daripada taraf signifikan 5\% (table 3). Umumnya perusahaan di Indonesia belum melakukan efisiensi terhadap fixed financial assetsnya, sehingga tidak dapat meningkatkan kapasitas produksi. Fixed financial assets yang tinggi akan menyebabkan biaya yang tinggi kemudian dapat mengurangi gross operating income.

\section{Number of Days Account Receivable}


Number of days accounts receivable tidak mempunyai pengaruh terhadap gross operating income. Hal ini dibuktikan dengan nilai $\mathrm{Sig}=0,721$ lebih besar daripada taraf signifikansi 5\% (table 3). Hal ini tidak sesuai dengan penelitian Yunus (2005) dan Deloof (2003).Penurunan number of days accounts receivable akan mengakibatkan naiknya gross operating income. Teori menurut Brigham and Daves (2001 : 700) menyatakan bahwa semakin kecil number of days accounts receivable maka akan meningkatkan gross operating income.

\section{Cash Convertion Cycle}

Cash conversion cycle tidak mempunyai pengaruh yang signifikan terhadap profitabilitas perusahaan (gross operating income).Hal ini dapat dilihat dari nilai Sig $=$ 0,742 yang lebih besar daripada taraf signifikansi 5\% (table 3).Hasil penelitian ini sama dengan penelitian sebelumnya yang dilakukan oleh Yunus (2005) dan Deloof (2003) yang menyatakan bahwa tidak ada pengaruh yang signifikan antara cash conversion cycle dengan gross operating income.

\section{SIMPULAN}

Berdasarkan pembahasan yang telah diuraikan sebelumnya maka dapat diambil kesimpulan yaitu dalam pemodelan regresi linear di penelitian ini, variabel number of days account payable dikeluarkan dari persamaan regresi berganda.Hasil analisis regresi linear berganda menunjukkan bahwa manajemen modal kerja yang diproksi melalui Sales Growth Ratio, Financial Debt Ratio, Fixed Financial Ratio, Number of Days Account Receivable, Number of Days Inventories, dan Cash Convertion Cycle tidak berpengaruh secara simultan terhadap Profitabilitas Perusahaan (Gross Operating Income). Berdasarkan pengujian secara parsial, variabel modal kerja yang 
mempengaruhi secara signifikan terhadap profitabilitas perusahaan adalah number of days inventories.Peneliti menyarankan perlunya mengembangkan dengan memperluas penelitian pengaruh modal kerja perusahaan di berbagai sector industri sehingga bisa diketahui kondisi perusahaan jika ditinjau dari segi profitabilitasnya di sector industri mana saja yang rentan terhadap tidak stabilnya kondisi ekonomi Indonesia. Selanjutnya, direkomendasikan untuk mengembangkan penelitian ini di masa akan datang untuk melakukan pengujian terhadap konsistensi penelitian ini dengan mengembangkan variabel yang diteliti dan metodologi penelitiannya.

\section{DAFTAR PUSTAKA}

Beodijoewono, Noegroho, Pengantar Statistik: Ekonomi Dan Perusahaan Jilid 2 Edisi Revisi. Yogyakarta: Unit Penerbit Dan Percetakan AMP YKPN.

Brigham, Eugene F and Daves, Philip R *(2001), Intermediate Financial Management. UK: Thomson Learning.

Van Horne, James C and Wachowicz, John M (1997), Prinsip-prinsip Manajemen Keuangan. INDONESIA: Salemba Empat

Sartono, Agus (2001), Manajemen Keuangan Teori dan Aplikasi Edisi 4, Yogyakarta:BPFE

Smith, Jay M; Skousen, K. Fred; Stice, James D, Intermediate Accounting $12^{\text {th }}$ Ed.USA: SouthWsternCollege Publishing.

Weston, J. Fred and Brigham, Eugene F (1992), Manajemen Keuangan Edisi 9. INDONESIA: Erlangga.

Achmad, Kamarudin (1997), Dasar-dasar Manajemen Modal Kerja. INDONESIA: Rineka Cipta.

Deloof Marc, "Does Working Capital Management Affect Profitablity of Belgian Firms?". Journal of Business Finance and Accounting, 30 (3) \& (4), April/May 2003.

Harijono, Try dan Pribadi, Dody Wisnu. "Investasi Di Era Konsumsi”. Kompas, 20 April 2003. 
Ridwan (2004), Metode dan Teknik Menyusun Tesis, Bandung:Alfabeta. 